\title{
Stability of Kiwi Varieties of 'Hayward' in Powder During Storage
}

Inacia dos Santos Moreira, Jacinete Pereira Lima, Deise Souza de Castro, Wilton Pereira da Silva, Josivanda Palmeira Gomes, Henrique Valentim Moura, Luzia Marcia de Melo Silva, Jemima Ferreira Lisbôa, Yvana Maria Gomes dos Santos, Cleide Maria D. P. S. E. Silva

Federal University of Campina Grande (UFCG)

Tel: 55-083 2101-1055 E-mail: inaciamoreira@ymail.com

Received: Oct. 23, 2019 Accepted: Dec. 11, 2019 Published: Dec. 23, 2019

doi:10.5296/jas.v8i2.15689ＵＵＵ： Uttps://doi.org/10.5296/jas.v8i2.15689

\begin{abstract}
For the preservation of products obtained by dehydration, it is necessary to evaluate their physicochemical characteristics during storage. It was proposed, in the present study, to evaluate the stability of the kiwi cv. 'Hayward' powder, obtained at temperatures of 60 and $70{ }^{\circ} \mathrm{C}$ during its storage in laminated packages under controlled conditions of temperature (25 ${ }^{\circ} \mathrm{C}$ ) and relative humidity $(75 \%)$ for 90 days. The parameter's evaluated were: moisture content, ashes, soluble solids, titratable acidity (\% citric acid), $\mathrm{pH}$, water activity at $25{ }^{\circ} \mathrm{C}$, color for the parameters lightness $\left(\mathrm{L}^{*}\right)$ and chromaticity $\left(+\mathrm{a}^{*}\right.$ red; $-\mathrm{a}^{*}$ green; $+\mathrm{b}^{*}$ yellow; and -b* blue), phenolic compounds, flavonoids, total chlorophyll and carotenoids. It was observed that, after the 90 days, for the powder obtained at $70{ }^{\circ} \mathrm{C}$, the soluble solids and $\mathrm{pH}$ values were altered by the storage, which did not occur for the powder obtained at $60{ }^{\circ} \mathrm{C}$. For both powders, the content of ash and bioactive compounds were not affected by storage. The parameter of lightness decreased in both powders. The powder obtained at $70{ }^{\circ} \mathrm{C}$ proved to be better, showing lower content of moisture and total water activity, as well as the highest values of bioactive compounds.
\end{abstract}

Keywords: actinidia deliciosa, bioactive compounds, fruit powder, drying

\section{Introduction}

Known as kiwifruit, kiwi or Chinese gooseberry, Actinidia deliciosa is the fruit of a climbing plant belonging to the Actinidiaceae family, by the origin from Yang-Tzé river valley in China, where it is known as 'minoutao', meaning 'monkey peach'. It extensively develops in habitats where forests and mountains prevail, with predominance of temperate climate. The fruit has oval and flattened shape, light brown peel covered by hair and its pulp is greenish, with tiny edible black seeds in the center (Souza et al., 1996; Disqual, 2012). More than 70 
species of kiwi are cultivated globally, among which the varieties 'Hayward' and 'Qinmei' are the main cultivars planted in the world (Garcia et al., 2012).

As agricultural products produced in large quantities are not consumed immediately, because theirs period of durability are very short. Keeping these products fresh is possible with some special operations (Ozgen and Celik, 2019). The fruits in particular, due to the high moisture content, are very susceptible to deterioration by the action of microorganisms. Thus, the utilization of drying has been increasingly widespread because, in addition to offering a good quality product, this process allows longer storage and shelf life (Silva et al., 2016).

Despite the guarantees proposed with the drying process, it is through the monitoring of the packaged product that the consumer can have access to the real conditions of the food before consumption. The package is in contact with the food and can be considered the simplest and most viable tool to provide information on the quality of the packaged food during transport and storage (Oliveira et al., 2015).

There are several studies seeking to understand the stability of food products during their storage, such as Galdino et al. (2016), studying the stability of cactus pear (Opuntia ficus-indica) powder, Conegero et al. (2017), studying 'mangaba' (Hancornia speciosa Gomes) pulp powder, Rodrigues et al. (2018) evaluating a byproduct of 'jabuticaba' (Plinia cauliflora) stored in microcapsules, and Sousa et al. (2016) evaluating the stability of cashew (Anacardium occidentale L.) juice powder dehydrated in a spouted bed.

Based on the above data, this study was conducted to evaluate the stability of kiwi powders obtained at temperatures of $60{ }^{\circ} \mathrm{C}$ and $70{ }^{\circ} \mathrm{C}$ during storage in laminated packages under controlled conditions of temperature $\left(25^{\circ} \mathrm{C}\right)$ and relative humidity $(75 \%)$ for 90 days.

\section{Material and Methods}

Kiwifruits of the variety 'Hayward' were purchased at EMPASA - Paraíba's Company of Supply and Agricultural Services in the city of Campina Grande, Paraíba state, Brazil, at the commercial maturity stage. After the acquisition, the fruits were taken to the Laboratory of Storage and Processing of Agricultural Products (LAPPA).

In the laboratory, the fruits were selected based on maturity stage, discarding those that were unsatisfactory. The rest of them were washed in running water and sanitized with a $15 \%$ sodium hypochlorite solution for $5 \mathrm{~min}$.

After the moist peel was air dried, the fruits were peeled with stainless steel knives. The fruits were cut into circular slices with about $49 \mathrm{~mm}$ diameter and $5 \mathrm{~mm}$ thickness. These slices were dried in a forced air circulation oven (Marconi brand, MA 035/3IN250 model) regulated to operate at temperatures of 60 and $70{ }^{\circ} \mathrm{C}$, until they reached the equilibrium moisture content. After drying, the kiwi slices were subjected to the grinding process to obtain the powder.

\subsection{Accelerated Storage}

Kiwi powders dried at temperatures of 60 and $70{ }^{\circ} \mathrm{C}$ were placed in a metalized stand-up zipper pouch 100, composed of transparent PET/metallization/low-density polyethylene (LDPE) film. The packages were sealed in a mechanical sealing machine. The packed and 


\section{Macrothink}

Journal of Agricultural Studies

ISSN 2166-0379

2020, Vol. 8, No. 2

sealed samples were transferred to airtight glass containers containing saturated solution of sodium chloride $(\mathrm{NaCl})$, which promoted average relative humidity to $75 \%$ at $25^{\circ} \mathrm{C}$. The containers with the packed samples were taken to BOD-type chambers at $25^{\circ} \mathrm{C}$.

During the storage, powder's stability was monitored through the periodic analyses of physical and physicochemical characteristics performed in the initial time (zero time - after processing) and then every 15 days, till 90 days, by the determination of quality parameters: moisture content, ash, soluble solids, titratable acidity (\% citric acid) and $\mathrm{pH}$ by the methodologies of IAL (2008). The water's activity at $25^{\circ} \mathrm{C}$ was quantified by the direct reading of AquaLab (Decagon). The color was determined in a portable spectrophotometer (HunterLab - MiniScan XE Plus 4500 L), obtaining the parameters of lightness (L*) and chromaticity $\left(+a^{*}\right.$ red; $-a^{*}$ green; $+b^{*}$ yellow; and $-b^{*}$ blue); phenolic compounds (Waterhouse, 2006) and flavonoids (Francis, 1982). The total chlorophyll and carotenoids were determined according to Lichtenthaler (1987).

\subsection{Statistical Analysis}

The experiment was installed in a completely randomized design, in a $2 \times 7$ factorial scheme, the first factor corresponding to the drying temperatures $\left(60\right.$ and $\left.70{ }^{\circ} \mathrm{C}\right)$ and the second to the storage time $(0,15,30,45,60,75$ and 90 days). The results were subjected to the analysis of variance, and based on these results, considering the effects of the interactions between the factors and verifying significant effects of the interactions, they were subjected to regression analysis, in which linear and nonlinear models were selected based on the F test significance of each model tested and on the coefficient of determination.

\section{Results and Discussion}

Figure 1 show the results of moisture content and water's activity (Aw) of kiwi powder dehydrated at temperatures of 60 and $70{ }^{\circ} \mathrm{C}$, during the 90 days of storage under controlled conditions of temperature $\left(25^{\circ} \mathrm{C}\right)$ and relative humidity $(75 \% \mathrm{RH})$. 
A

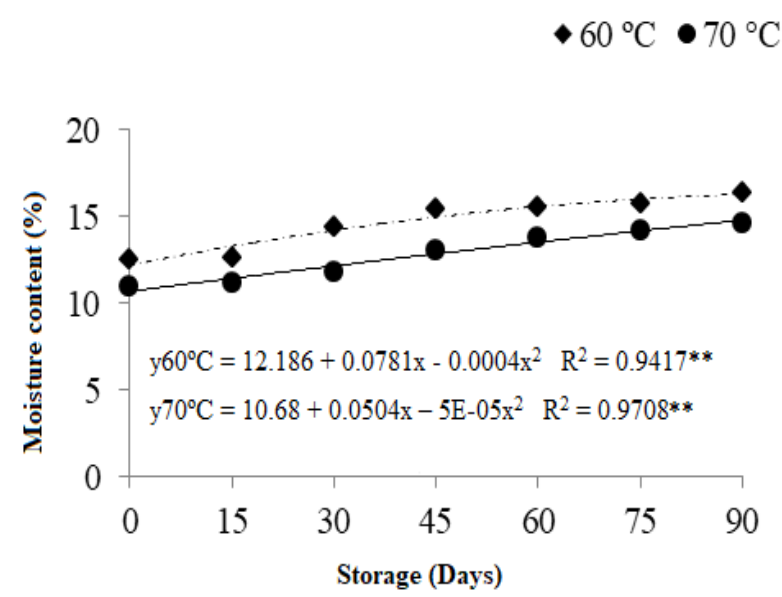

B

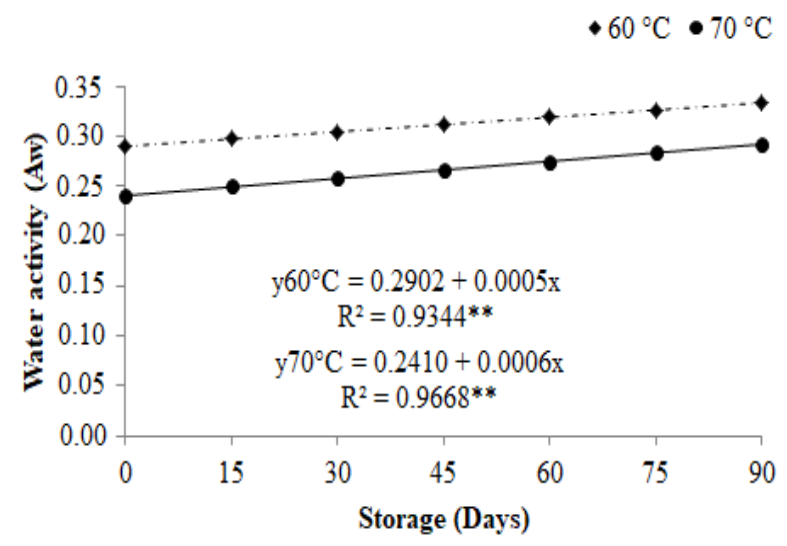

Figure 1. (A) Moisture content (\%) and (B) Water's activity (Aw) in kiwi powder dehydrated at the temperatures of 60 and $70{ }^{\circ} \mathrm{C}$ during 90 days of storage at $25^{\circ} \mathrm{C}$ and $75 \% \mathrm{RH}$

$* *$ Significant at $\mathrm{p} \leq 0.01$

The moisture contents of kiwi powders dehydrated at temperatures of 60 and $70{ }^{\circ} \mathrm{C}$ showed a statistically significant difference $(\mathrm{p}<0.01)$ during the storage and quadratic polynomial behavior, with a tendency to increase.

The highest values of moisture content was observed for the powder dehydrated at $60{ }^{\circ} \mathrm{C}$, with value of $12.49 \%$ at the initial time and reaching $16.38 \%$ at the end of the storage. The samples dehydrated at $70{ }^{\circ} \mathrm{C}$ at the beginning of the storage contained moisture content of $10.92 \%$, reaching $14.65 \%$ at 90 days of storage, compared to the powder dehydrated at $60{ }^{\circ} \mathrm{C}$. This demonstrated that the used packaging allowed the diffusion of water from the environment to the kiwi powders. Although the laminated package has low permeability, its sealing may have compromised the airtight closure, that allows some water absorption during the storage.

The laminated package did not prevent the water's absorption by the kiwi powder, but the legislation establishes that the maximum moisture content for dehydrated fruits should be equal to $25 \%$ (Brasil, 2005). Thus, the kiwi powders dried at temperatures of 60 and $70{ }^{\circ} \mathrm{C}$ are within the standards required by the current legislation during the 90 days of storage.

This phenomenon is in agreement with Santos et al. (2016), who reported an increase in the moisture content of 'umbu-cajá' (Spondias spp.) pulp along the 180 days of storage under ambient conditions. Juliano et al. (2014) also reported an increase in the moisture content of camu-camu (Myrciaria dubia) pulp powders along 150 days of storage at $25{ }^{\circ} \mathrm{C}$.

Loureiro et al. (2013), in a study with 'buriti' (Mauritia flexuosa) powder obtained by drying in an oven at 50,60 and $70{ }^{\circ} \mathrm{C}$, found in samples dehydrated at $50{ }^{\circ} \mathrm{C}$ and stored in laminated packaging, that the moisture content remained statistically unchanged until the 75 days of storage and statistically significant increased between 75 and 90 days, with a percentage increase of $4.3 \%$ in the period from zero to 90 days. At the drying temperatures of 60 and 70 ${ }^{\circ} \mathrm{C}$, the samples stored in laminated packaging did not show statistically significant 
alterations.

Lisbôa et al. (2012), when evaluating the storage of cactus pear powder in laminated packages for 100 days at different temperatures and relative humidities, verified a significant increase in the moisture content of the samples.

The water's activity (Aw) values of kiwi powder dehydrated at temperatures of 60 and $70{ }^{\circ} \mathrm{C}$ increased significantly $(\mathrm{p}<0.01)$ along the storage, showing a linear behavior, with tendency to increase (Figure 1B). Kiwi powder obtained with drying at $60^{\circ} \mathrm{C}$ had a mean Aw values of 0.285 and 0.330 for the initial time and final time of storage, respectively, while the powder dried at $70{ }^{\circ} \mathrm{C}$ had Aw of 0.243 to 0.297 for the initial time and 90 days of storage, respectively. The increase in the water's activity can be justified by the increase in the moisture content of kiwi powders. This behavior is similar to that observed by other authors for fruit powders during storage.

Conegero et al. (2017) observed increase in the water's activity, evaluating the stability of 'mangaba' (Hancornia speciosa Gomes) powder along the 90 days of storage. Santos et al. (2016) stored 'umbu-cajá' (Spondias spp.) powder and reported an increase in water activity along the storage. Oliveira et al. (2015), evaluating 'mandacaru' (Cereus jamacaru) during storage, observed an increase in water activity (Aw) along the 50 days of storage. Costa et al. (2013) observed an increase in water activity during storage with values between 0.42 and 0.47 in the stability of passion fruit powder. Lisbôa et al. (2012), evaluating cactus pear powder, also verified a consistent increase in water activity over the 100 days of storage.

Rahman (1995) reported that the loss of quality of dry foods begins to increase of the water's activity (Aw) higher than 0.3, and foods with Aw greater than 0.6, are more prone for the growth of microorganisms, molds and yeasts. However, the values found in all kiwi powders evaluated are considered safe with respect to the alterations caused by the growth of pathogenic bacteria, since these microorganisms are unable to develop at these values of the water's activity.

The Figure 2 shows results of the contents of ashes and soluble solids of kiwi powder dried at temperatures of 60 and $70{ }^{\circ} \mathrm{C}$, as a function of the storage time (90 days) under controlled conditions of temperature $\left(25^{\circ} \mathrm{C}\right)$ and relative humidity $(75 \% \mathrm{RH})$. 
A

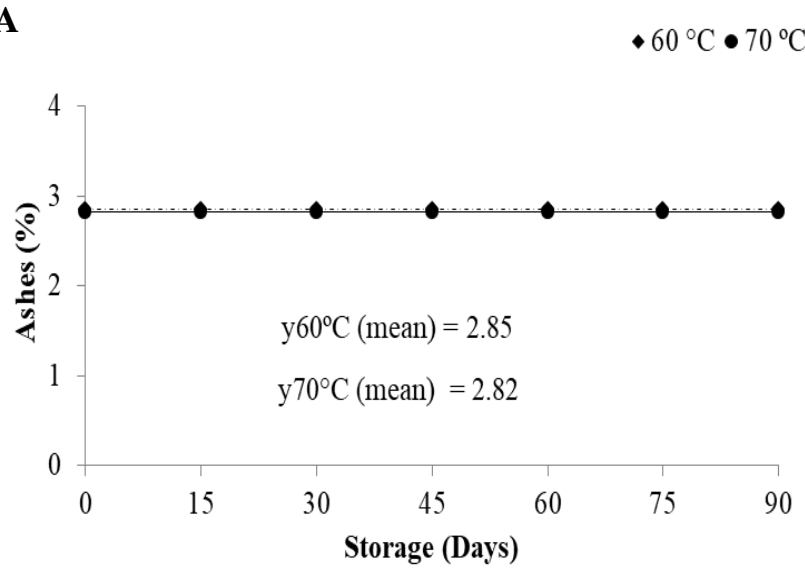

B 2020, Vol. 8, No. 2

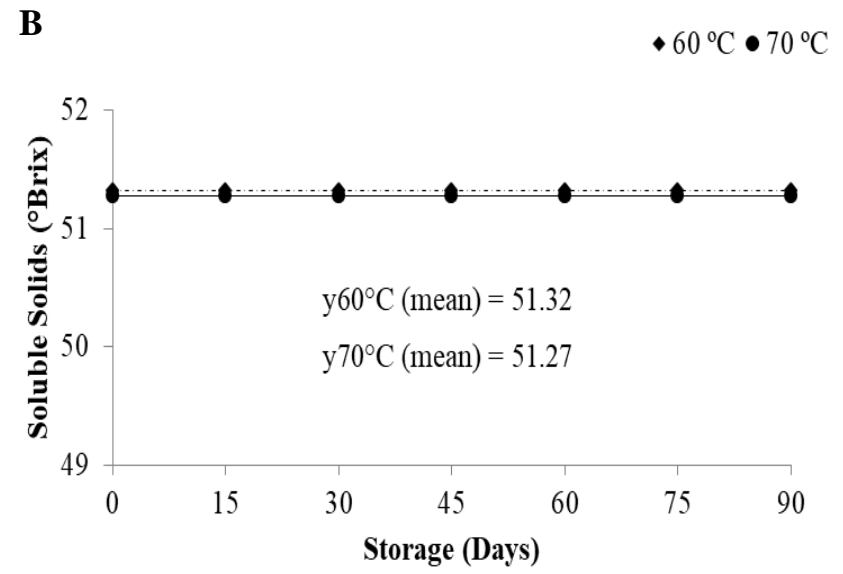

Figure 2. Contents of (A) ashes and (B) soluble solids in kiwi powder dehydrated at temperatures of 60 and $70{ }^{\circ} \mathrm{C}$ during 90 days of storage at $25^{\circ} \mathrm{C}$ and $75 \% \mathrm{RH}$

It was observed that the ash contents of kiwi powders dried at both temperatures were not influenced by the storage time, showing mean values of 2.85 and $2.82 \%$ for the powder obtained at temperatures of 60 and $70{ }^{\circ} \mathrm{C}$, respectively (Figure $2 \mathrm{~A}$ ).

Figure $2 \mathrm{~B}$ showed that the soluble solids content of samples dehydrated at 60 and $70{ }^{\circ} \mathrm{C}$ were stable along the storage time, with mean values equal to 51.32 and $51.27^{\circ}$ Brix, respectively.

Loureiro et al. (2013) observed a reduction in the soluble solids content of 'buriti' (Mauritia flexuosa) powder at the end of 90 days of storage. These authors reported that the reduction in soluble solids content may be due to increase of moisture content during storage, altering the proportion of solids in the total mass. Costa et al. (2013) observed reduction in the values of soluble solids in passion fruit powder at the end of 360 days of storage. Santos et al (2016) also reported a reduction in soluble solids content in 'umbu-cajá' (Spondias spp.) powder during the 180 days of storage.

The results of titratable acidity (TA) and $\mathrm{pH}$ of kiwi powders dehydrated at 60 and $70{ }^{\circ} \mathrm{C}$ during 90 days of storage under controlled conditions of temperature $\left(25^{\circ} \mathrm{C}\right)$ and relative humidity $(75 \%)$ are presented in Figure 3. 

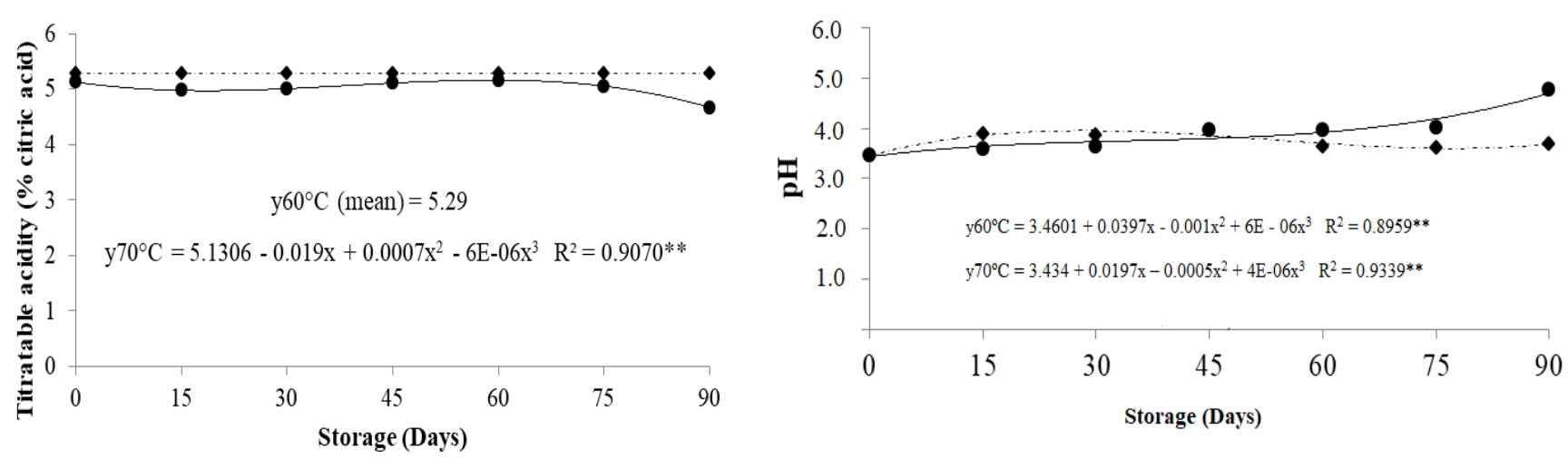

Figure 3. (A) Titratable acidity (\% in citric acid) and (B) $\mathrm{pH}$ of 'Hayward' kiwi powder dehydrated at temperatures of 60 and $70{ }^{\circ} \mathrm{C}$ during 90 days of storage at $25^{\circ} \mathrm{C}$ and $75 \% \mathrm{RH}$ $* *$ Significant at $\mathrm{p} \leq 0.01$

According to Figure $3 \mathrm{~A}$, the acidity of kiwi powder dehydrated at $60{ }^{\circ} \mathrm{C}$ remained stable over the 90 days of storage, with mean values of $5.29 \%$ citric acid. In the kiwi powder obtained at drying temperature of $70{ }^{\circ} \mathrm{C}$, the total titratable acidity showed a statistically significant difference $(\mathrm{p}<0.01)$ during storage, with a cubic behavior, but a slight tendency to decrease, especially from 15 to 30 days of storage. Subsequently, there was an increase at 45 days, followed by a reduction from 75 days. These fluctuations in the mean values of total titratable acidity were 5.10 and $4.66 \%$ citric acid at the time zero and at 90 days of storage, respectively, with no specific behavior.

The $\mathrm{pH}$ of kiwi powder dried at temperature of $60{ }^{\circ} \mathrm{C}$ showed a statistically significant difference $(\mathrm{p}<0.01)$ during storage and a cubic behavior, with a tendency to increase, especially from 15 to 30 days of storage (Figure 3B). Subsequently, there was a slight decrease at 45 days, followed by a tendency to stability from 60 days of storage. Values between 3.46 and 3.95 represent a narrow variation of $\mathrm{pH}$, but no specific behavior was observed for this variable.

In the kiwi powder dehydrated at $70{ }^{\circ} \mathrm{C}$, there was a statistically significant difference $(\mathrm{p}<0.01)$ during storage, showing a linear behavior, with tendency to increase, and values between 3.37 and 4.46 at the initial time and at the end of storage, respectively.

For showing $\mathrm{pH}<4.5$, the kiwi powder dried at 60 and $70{ }^{\circ} \mathrm{C}$ is considered an acidic food. Along with the low water's activity, that can promote the microbiological stability in the powder along the 90 days of storage.

The Figure 4 presents the values of lightness $\left(\mathrm{L}^{*}\right)$, red intensity, yellow intensity, chromaticity $\left(\mathrm{C}^{*}\right)$ and hue angle $\left(\mathrm{h}^{\circ}\right)$ of kiwi powders dehydrated at 60 and $70{ }^{\circ} \mathrm{C}$ during 90 days of storage under controlled conditions of temperature $\left(25^{\circ} \mathrm{C}\right)$ and relative humidity $(75 \%)$. 
A

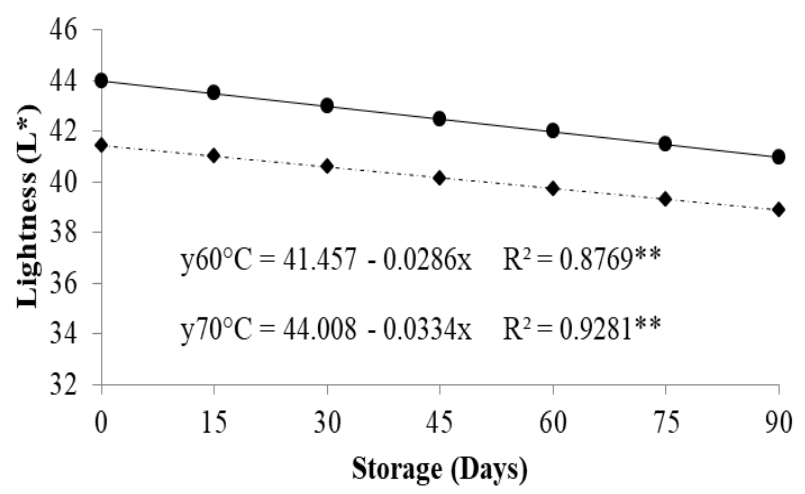

C

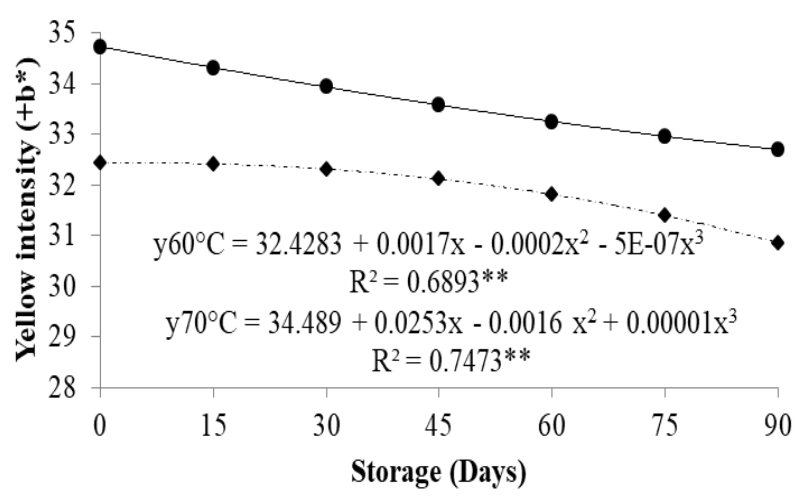

$\mathbf{E}$

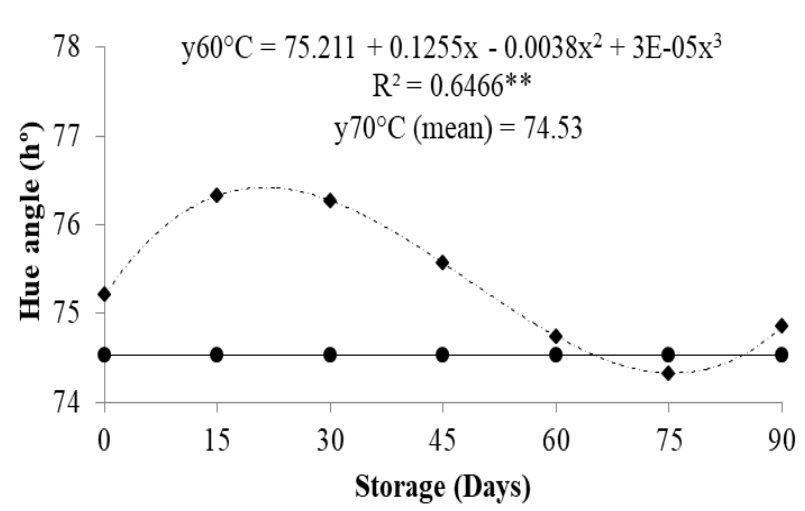

B

$\bullet 60^{\circ} \mathrm{C} \cdot 70^{\circ} \mathrm{C}$

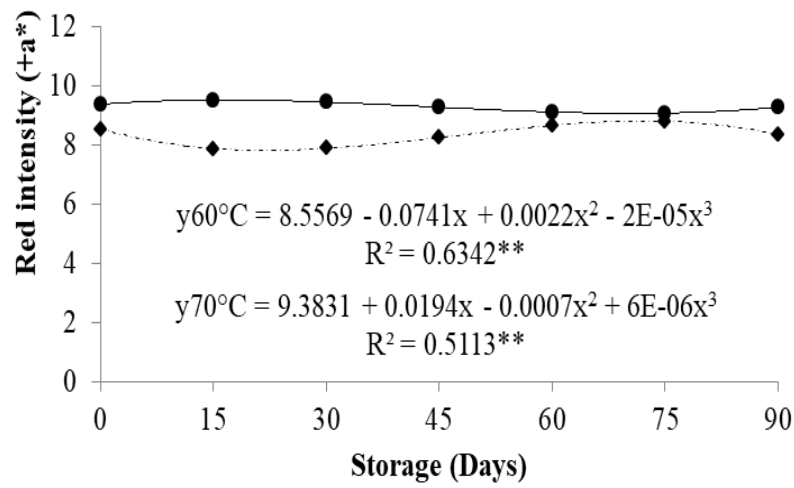

D - $60{ }^{\circ} \mathrm{C} \bullet 70^{\circ} \mathrm{C}$

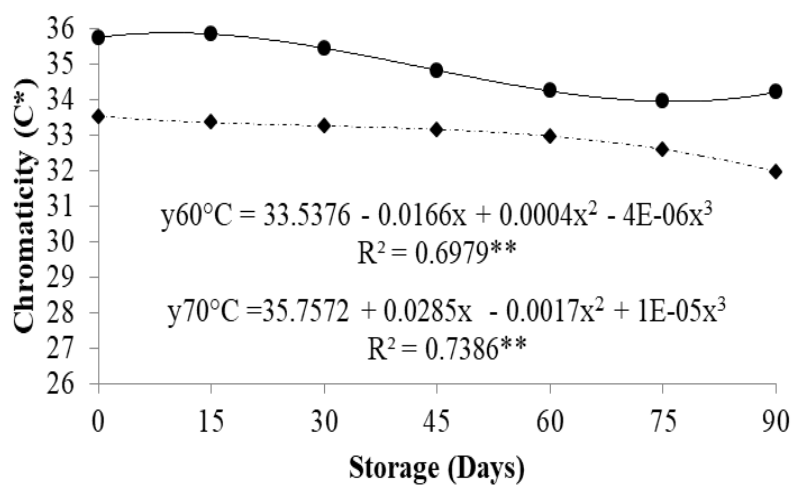

Figure 4. (A) Lightness (L*); (B) Red intensity; (C) Yellow intensity; (D) Chromaticity (C*) and (E) Hue angle $\left(\mathrm{h}^{\circ}\right)$ in kiwi powder dehydrated at temperatures of 60 and $70{ }^{\circ} \mathrm{C}$ during 90 days of storage at $25^{\circ} \mathrm{C}$ and $75 \% \mathrm{RH}$

** Significant at $\mathrm{p} \leq 0.01$

The lightness of kiwi powders decreased linearly with the advance of storage time, indicating their darkening, that can be attributed mainly to non-enzymatic reactions. The kiwi powder dried at $70^{\circ} \mathrm{C}$ showed higher lightness during the storage when compared to the kiwi powder dried at $60{ }^{\circ} \mathrm{C}$ (Figure 4A). Similar results were reported by Oliveira et al. (2015), who 
evaluated the stability of 'mandacaru' (Cereus jamacaru) pulp powder and observed a decrease in lightness $\left(\mathrm{L}^{*}\right)$, which led to darkening of the sample along the storage time.

Juliano et al. (2014), evaluating the shelf life of camu-camu (Myrciaria dubia) powder, also verified that the lightness of the product was reduced during storage. These authors reported that there are several factors which may influence the darkening of dehydrated products, such as non-enzymatic reactions (Maillard, caramelization and oxidation of organic acids), high water activity, storage temperature, $\mathrm{pH}$ and chemical composition of the food.

According to Kader (2010), the value of lightness is an indicator of darkening along the storage, which can be caused by both oxidative reactions and increased concentration of pigments.

For the $\left(\mathrm{a}^{*}\right)$ coordinate in the kiwi powder samples dehydrated at 60 and $70{ }^{\circ} \mathrm{C}$, there was a significant difference $(\mathrm{p}<0.01)$ during storage, showing a cubic behavior (Figure 4B).

Through the Figure $4 \mathrm{~B}$, it can be observed that the red intensity $\left(+\mathrm{a}^{*}\right)$ of kiwi powder dried at $60{ }^{\circ} \mathrm{C}$ tended to decrease, especially from 15 to 45 days of storage, with a tendency to increase from 60 days of storage.

Along the storage, the red intensity $\left(+\mathrm{a}^{*}\right)$ of kiwi powders dehydrated at $70{ }^{\circ} \mathrm{C}$ remained constant until 45 days, with a tendency to a slight reduction from 60 days of storage. However, along the entire storage time, the kiwi powder dried at $70{ }^{\circ} \mathrm{C}$ showed higher red intensity than that dried at $60{ }^{\circ} \mathrm{C}$.

For the $\left(b^{*}\right)$ coordinate, the kiwi powders dehydrated at 60 and $70{ }^{\circ} \mathrm{C}$ showed a statistically significant difference $(\mathrm{p}<0.01)$ along the storage, exhibiting a cubic behavior (Figure 4C). The yellow intensity $\left(+b^{*}\right)$ of kiwi powder dried at $60^{\circ} \mathrm{C}$ showed no specific behavior during storage. The yellow intensity $\left(+b^{*}\right)$ of the kiwi powder dehydrated at $70{ }^{\circ} \mathrm{C}$ tended to decrease from 15 days of storage. This type of degradation, which results in color changes, is common when the product is subjected to a long storage time and was evidenced by Santos et al. (2016) in 'umbu-cajá' (Spondias spp.) powder stored for 180 days.

However, the yellow intensity $\left(+b^{*}\right)$ of kiwi powder dehydrated at $70{ }^{\circ} \mathrm{C}$ was higher than the values found for kiwi powder dried at $60{ }^{\circ} \mathrm{C}$ during the 90 days of storage.

Chromaticity $\left(\mathrm{C}^{*}\right)$ showed a statistically significant difference $(\mathrm{p}<0.01)$ in the kiwi powders produced at temperatures of 60 and $70{ }^{\circ} \mathrm{C}$ during storage, with a cubic behavior (Figure 4D).

In the kiwi powder dried at $60{ }^{\circ} \mathrm{C}$, there was a tendency to stability from the initial time to 60 days of storage, with a tendency to decrease at 75 days. For the kiwi powder obtained after dehydration at $70{ }^{\circ} \mathrm{C}$, a decrease in this variable was consequently found from 45 days of storage, with a tendency to stability from 60 days, which indicates a reduction in the color intensity of the kiwi powders during storage.

However, the kiwi powder obtained at temperature of $70{ }^{\circ} \mathrm{C}$ showed higher value of chromaticity $\left(\mathrm{C}^{*}\right)$ during storage, indicating that the color of the samples was more saturated in comparison to that of the powder obtained at $60{ }^{\circ} \mathrm{C}$. 
In the kiwi sample dehydrated at $60{ }^{\circ} \mathrm{C}$, there was a statistically significant difference $(\mathrm{p}<0.01)$ in the hue angle $\left(\mathrm{h}^{\circ}\right)$ during storage, showing a cubic behavior (Figure 4E). Fluctuations in this variable were observed during storage, with a consequent increase from 15 to 30 days of storage, then a slight decrease until 75 days, followed by a slight increase at the end of storage. Along the storage, the hue angle ranged from 74.33 to 76.33 , which represents a small variation for this characteristic (Figure 4E).

Santos et al. (2016) studied the stability of the lyophilized 'umbu-cajá' (Spondias spp.) pulp during 180 days of storage and observed a reduction in the hue angle of the powder sample formulated with $10 \%$ of arabica gum (G10).

The hue angle of the kiwi powder dried at $70{ }^{\circ} \mathrm{C}$ did not vary during storage, showing a mean value of 74.53 .

Figure 5 shows the results of the total phenolic compounds and flavonoids of kiwi powders dehydrated at the temperature of 60 and $70{ }^{\circ} \mathrm{C}$, during 90 days of storage under controlled conditions of temperature $\left(25^{\circ} \mathrm{C}\right)$ and relative humidity $(75 \%)$.
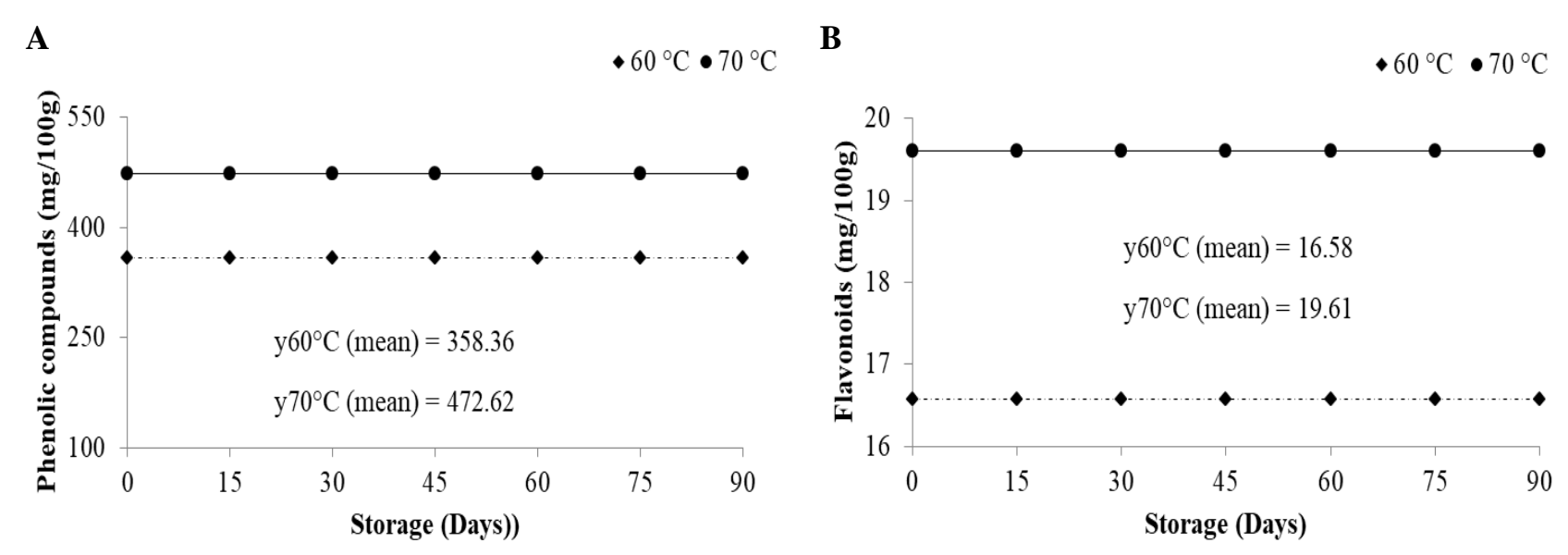

Figure 5. (A) Phenolic compounds and (B) flavonoids in 'Hayward' kiwi powder dehydrated at temperatures of 60 and $70{ }^{\circ} \mathrm{C}$ during 90 days of storage at $25^{\circ} \mathrm{C}$ and $75 \% \mathrm{RH}$

As observed in Figure 5A, the phenolic compounds content in the kiwi powders did not vary along the storage, with mean values of 358.36 and $472.62 \mathrm{mg} / 100 \mathrm{~g}$ for the powders produced at temperatures of 60 and $70{ }^{\circ} \mathrm{C}$, respectively.

According to Chitarra and Chitarra (2005), the phenolic compounds participate in flavor, color, shelf life and in the action of the product as functional food, notably correlated with the antioxidant capacity.

The content of flavonoids was not influenced by the storage time, with mean values of 16.59 and $19.61 \mathrm{mg} / 100 \mathrm{~g}$ for the powders obtained at 60 and $70{ }^{\circ} \mathrm{C}$, respectively (Figure 5B).

The results referring to total chlorophyll and total carotenoids of kiwi powders dried at temperatures of 60 and $70{ }^{\circ} \mathrm{C}$, as a function of the storage time (90 days) under controlled conditions of temperature $\left(25^{\circ} \mathrm{C}\right)$ and relative humidity $(75 \% \mathrm{RH})$ are presented in Figure 6. 
A

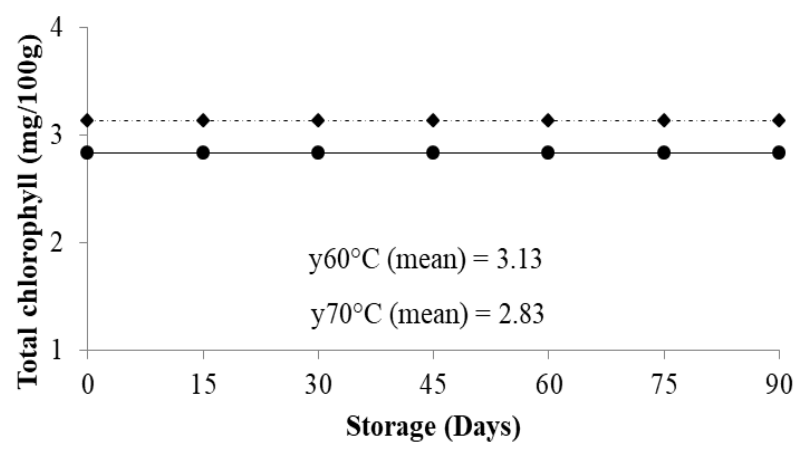

B

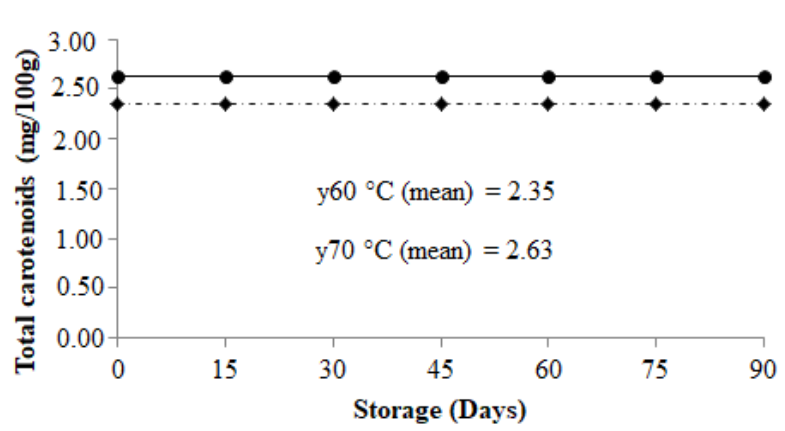

Figure 6. (A) Total chlorophyll and (B) Total carotenoids in 'Hayward' kiwi powder dehydrated at temperatures of 60 and $70{ }^{\circ} \mathrm{C}$ during 90 days of storage at $25{ }^{\circ} \mathrm{C}$ and $75 \% \mathrm{RH}$

There was no variation of total chlorophyll in the kiwi powders dehydrated at 60 and $70{ }^{\circ} \mathrm{C}$ along the 90 days of storage, with mean values of 3.13 and $2.83 \mathrm{mg} / 100 \mathrm{~g}$ for the powders obtained at temperatures of 60 and $70{ }^{\circ} \mathrm{C}$, respectively.

The kiwi powder dehydrated at $60{ }^{\circ} \mathrm{C}$ showed a significant difference $(\mathrm{p}<0.01)$ in the content of total carotenoids during storage, exhibiting a cubic behavior, with tendency to decrease, especially from 30 to 70 days, followed by an increment at 90 days of storage. Its mean values were between 2.60 and $2.00 \mathrm{mg} / 100 \mathrm{~g}$, at the beginning of storage and at 60 days of storage, respectively (Figure 6).

\section{Conclusions}

The moisture content and water's activity increased during the storage of kiwi powder dried at temperatures of 60 and $70{ }^{\circ} \mathrm{C}$. The soluble solids, titratable acidity and $\mathrm{pH}$ of kiwi powder obtained at the temperature of $70{ }^{\circ} \mathrm{C}$ were statistically significantly altered along the storage. In the kiwi powder dehydrated at $60{ }^{\circ} \mathrm{C}$, the content of soluble solids, titratable acidity and $\mathrm{SS} / \mathrm{TA}$ ratio were not altered along the storage;

The contents of ashes and bioactive compounds such as phenolic compounds, flavonoids, anthocyanins, total chlorophyll and carotenoids were not altered during the storage of kiwi powder obtained at temperatures of 60 and $70{ }^{\circ} \mathrm{C}$;

The values of lightness, yellow intensity $\left(+b^{*}\right)$ and chromaticity $\left(C^{*}\right)$ were reduced with the advance in the storage time of kiwi powders dried at the two temperatures evaluated;

The temperature of $70{ }^{\circ} \mathrm{C}$ was the best drying condition, leading to a powder with lower moisture content and water activity, as well as the highest content of bioactive compounds.

\section{References}

Brasil, Ministério da Saúde, Agência Nacional de Vigilância Sanitária. Resolução RDC n 272, de 22 de setembro de 2005. Aprova o regulamento técnico para produtos vegetais, produtos de frutas e cogumelos comestíveis. Diário Oficial da União; Poder Executivo, de 23 de setembro de 2005. 
Chitarra, M. I., \& Chitarra, A. B. (2005). Pós-colheita de frutos e hortaliças: fisiologia e manuseio. 2.ed. Lavras: UFLA, p.785.

Conegero, J., Ribeiro, L. C., Costa, J. M. C., \& Monteiro, A. R. G. (2017). Stability of 'mangaba' pulp powder obtained by freeze drying. Revista Brasileira de Engenharia Agrícola e Ambiental, 21(9), 645-650.

https://doi.org/10.1590/1807-1929/agriambi.v21n9p645-650

Costa, J. N., Figueiredo, R. W., Sousa, P. H. M., Gonzaga, M. L. C., Constant, P. B. L., \& Soares, D. J. (2013). Study of the stability of passion fruit (Passiflora edullis f. flavicarpa) powder from organic farming. Semina: Ciências Agrárias, 34(2), 705-716. https://doi.org/10.5433/1679-0359.2013v34n2p705

Disqual. Manual de boas práticas agrícolas: kiwi. Available at:

http://ebookbrowse.com/disqual-kiwi-pdf-d378215241. Accessed on: September 18, 2019. p. 25.

Francis, F. J. (1982). Analysis of anthocyanins. In: MARKAKIS, P. Anthocyanins as food colors. New York: Academic 181-207. https://doi.org/10.1016/B978-0-12-472550-8.50011-1

Galdino, P. O., Figueirêdo, R. M. F., Queiroz, A. J. M., Galdino, P. O., \& Fernandes, T. K. S. (2016). Stability of cactus-pear powder during storage. Revista Brasileira de Engenharia Agrícola e Ambiental, 20(2), 169-173.

https://doi.org/10.1590/1807-1929/agriambi.v20n2p169-173

Garcia, C. V., Quek, S. Y., Stevenson, R. J., \& Winz, R. A. (2012). Kiwifruit flavour: a review. Trends in Food Science \& Technology, 24, 82-91. https://doi.org/10.1016/j.tifs.2011.08.012

Instituto Adolfo Lutz - IAL. (2008). Normas Analíticas do Instituto Adolfo Lutz: Métodos Químicos e Físicos para Análise de Alimentos. 4. ed. São Paulo: IAL, p.1020.

Juliano, F. F., Silva, P. P. M., Casemiro, R. C., Costa, M. H., \& Spoto, M. H. F. (2014). Polpa de camu-camu liofilizada e armazenada em diferentes embalagens. Revista Brasileira de Tecnologia Agroindustrial, 8(2), 1374-1384.

https://doi.org/10.3895/S1981-36862014000200007

Kader, A. A. (2010). Future of modified atmosphere research. Acta Horticulturae, 857, 212-217. https://doi.org/10.17660/ActaHortic.2010.857.24

Lichtenthaler, H. K. (1987). Chlorophylls and carotenoids: pigments of photosynthetic biomembranes. Methods in Enzymology, 148, 350-382.

https://doi.org/10.1016/0076-6879(87)48036-1

Lisbôa, C. G. C., Figueiredo, R. M. F., \& Queiroz, A. J. M. (2012). Armazenamento de figo-da-índia em pó. Revista Brasileira de Engenharia Agrícola e Ambiental, 16(2), 216-221. https://doi.org/10.1590/S1415-43662012000200013 


\section{Macrothink}

Loureiro, M. N., Figueirêdo, R. M. F., Queiroz, A. J. M., \& Oliveira, E. N. A. (2013). Armazenamento de buriti em pó: Efeito da embalagem nas características físicas e químicas. Bioscience Journal, 29(5), 1092-1100.

Oliveira, A. S., Figueirêdo, R. M. F., Queiroz, A. J. M., \& Brito, J. G. (2015). Estabilidade da polpa do Cereus jamacaru em pó durante o armazenamento. Revista Brasileira de Engenharia Agrícola e Ambiental, 19(2), 147-153.

https://doi.org/10.1590/1807-1929/agriambi.v19n2p147-153

Ozgen, F., \& Celik, N. (2019). Evaluation of Design Parameters on Drying of Kiwi Fruit. Applied Sciences, 9(10), 1-13. https://doi.org/10.3390/app9010010

Rahman, S. (1995). Food Properties Handbook. CRC Press.

Rodrigues, L. M., Januário, J. G. B., Santos, S. S., Bergamasco, R., \& Madrona, G. S. (2018). Microcapsules of 'jabuticaba' byproduct: Storage stability and application in gelatin. Revista Brasileira de Engenharia Agrícola e Ambiental, 22(6), 424-429.

https://doi.org/10.1590/1807-1929/agriambi.v22n6p424-429

Santos, D. C., Rocha, A. P. T., Gomes, J. P., Oliveira, E. N. A., Albuquerque, E. M. B., \& Araujo, G. T. (2016). Storage of 'umbu-cajá' pulp powder produced by lyophilization. Revista Brasileira de Engenharia Agrícola e Ambiental, 20(12), 1118-1123.

https://doi.org/10.1590/1807-1929/agriambi.v20n12p1118-1123

Silva, R. B., Silva, F. S., Porto, A. G., \& Alves, A. P. (2016). Estudo da cinética de secagem de polpa de carambola. Revista Brasileira de Tecnologia Agroindustrial, 10(2), 2069-2080. https://doi.org/10.3895/rbta.v10n2.3261

Souza, P. V. D., Marodin, G. A. B., \& Barradas, C. I. N. (1966). Cultura do quivi. Porto Alegre: Cinco Continente.

Souza, S. L., Morais, B. A., Ribeiro, L. C., \& Costa, J. M. C. (2016). Stability of cashew apple juice in powder dehydrated in spouted bed. Revista Brasileira de Engenharia Agrícola e Ambiental, 20(7), 678-682. http://dx.doi.org/10.1590/1807-1929/agriambi.v20n7p678-682

Waterhouse, A. (2006). Folin-ciocalteau micro method for total phenol in wine. American Journal of Enology and Viticulture, 3-5.

https://doi.org/10.1590/1807-1929/agriambi.v20n7p678-682

\section{Copyright Disclaimer}

Copyright for this article is retained by the author(s), with first publication rights granted to the journal.

This is an open-access article distributed under the terms and conditions of the Creative Commons Attribution license (http://creativecommons.org/licenses/by/4.0/). 